\title{
Integrated Management and Host Plant Resistance Against Dry Root Rot [Macrophomina phaseolina (Tassi.) Goid] of Chickpea
}

\author{
Lalita Lakhran* and R.R. Ahir \\ Department of Plant Pathology, S.K.N. College of Agriculture, \\ Jobner 303329 Rajasthan, India \\ *Corresponding author
}

Keywords

Bio- agents,

Fungicides,

Macrophomina

phaseolina, Plant

extract, Root rot

Article Info

Accepted:

10 June 2018

Available Online:

10 July 2018

\section{A B S T R A C T}

The present experiment was planned integrated management of root rot pathogen in chickpea. Occurrence of root rot disease has become a major constraint in recent years for successful and profitable cultivation of chickpea. The efficacy of Bio-agent viz. Tricoderma viride, Organic amendment viz. neem cake, Plant extract, garlic, and Fungicide, Carbendanzim applied through seed treatment and soil application were evaluated against Macrophomina phaseolina causing root rot disease of Chickpea. Different alternative combination of most effective treatments that tested in pot conditions for controlling root rot of chickpea exhibited. Among the treatments soil application with neem cake@ @25g/ pot+ seed treatment with carbendazim @ 2g/kg seed (16.66 and $20.00 \%$ ) followed by seed treatment with Trichoderma viride @ $4 \mathrm{~g} / \mathrm{kg}$ seed + carbendazim @ $2 \mathrm{~g} / \mathrm{kg}$ seed (20.00 and 20.83\%) found most effective to reducing root rot incidence over control at 40 and 60 days after sowing respectively. Twenty -nine cultivars/ germplasms tested against dry root rot of chickpea in which none of cultivars found resistant. Entries H12-24, GNG 1958, IPC 2002-31, GNG 2299, IPC 10- 134, PG 0104, IPCK 2009 -165, GL 2003, H 12-26, IPC 2007-28, CSJ 515 and BG 0109 were found moderately resistance.

\section{Introduction}

Chickpea (Cicer arietinum L.) also known as Bengal gram is one of the most important winter season pulse crop grown in India. It is said to be one of the oldest pulse crop cultivated from ancient times over throughout the Asia. Chickpea is a member of family fabaceae and believed to be originated in South West Asia. Gram considered as the World's second most widely grown legume after beans (Phaseolus vulgaris). Its ability to form nitrogen-fixing nodules via interaction with rhizobia adds to its uniqueness which make it's a valuable crop for maintaining soil fertility (Ferguson et al., 2010). India is the largest producer and consumer of pulses in the world. However, India has the distinction of being the world's single largest producer of pulses, the difference in production and population ratio is significant. Macrophomina phaseolina (Tassi.) Goid has a wide host range and is responsible for causing losses on more than 500 cultivated and wild plant species 
(Khan, 2007). Chickpea is prone to several fungal diseases, among them dry root rot caused by Macrophomina phaseolina is a soil born pathogen, first reported on chickpea from India (Mitra, 1931). El-Araby (2009) observed symptoms including shrunken, unfilled pods and brown wilted attached to dead petioles and stems along with the stem cortex have been also report due to Macrophomina phaseolina causes charcoal rot in soybean. The fungus is mainly a soil dweller and spreads from plant to plant through irrigation water, food and implements and cultural operation. The sclerotia \& pycniospore may also become air borne and cause further spread of the pathogen (Rangaswami and Mahadevan, 2008). Dry root rot of chickpea caused by nectrotropic fungus Macrophomina phaseolina is emerging as a serious threat to the chickpea production worldwide (Pande and Sharma, 2010). (Bagri etal., 2004) observed that Chickpea suffers from seed and soil borne fungal diseases viz, black root rot, dry root rot, wet rootrot, seed rotting, root rot, stem rot, crown rot, foot rot, sclerotinia wilt and gray mould. The characteristic symptom of root rot was yellowing of the leaves and within two of three days these leaves may drop off. The plant may wilt within a week. On the stem dark lesions may be seen on the bark at the ground level. If the plants are pulled out from the soil and examined the basal stem and main roots show root rot symptoms. In advance stage scattered sclerotial bodies may be seen on the affected tissues (Singh and Srivastava, 1988). In India Madhya Pradesh, Karnataka, Andhra Pradesh, Chhattisgarh or Central and Northern parts are affected by dry root rot of chickpea (Ghosh et al., 2013). Dry root rot chickpea caused 10-25\% losses (Pal, 1998) but it become severe in most of chickpea growing areas and caused more than 50\% losses (Massoud and Shiv Kumar, 2001). In order to achieve this, it is ascertain the proper management of diseases and use of integrated approaches. Management of soil borne fungal pathogens is difficult to control due to its long-term survival and wide host range of the pathogens. These pathogens not only persist in the soil as saprophytes along with other soil organisms but also are transmitted from seed. Different fungicides are being used in the management of soil borne diseases including dry root rot of greengram. However, chemical management is uneconomical, hazardous; disturb the biological balance cause ground water pollution, leaves residues on food crops and results in development of resistance in pathogens to the chemicals and ultimately breakdown the varietal resistances the promising approach for management of soil borne diseases. The present investigation was carried out to find the potential of IDM to manage this disease and host plant resistance.. Sources of resistance to vascular wilt have been reported from different part of the country but only a few moderate resistant lines/ germplasms to dry root rot are available. Therefore, commercial cultivars with genetic resistance to the disease have not yet been developed (Pande et al., 2004). Keeping the above facts in view, an investigation was undertaken with an objective to identify the sources of resistance in different genotypes of desi and kabuli chickpea.

\section{Materials and Methods}

The experiment was conducted under cage house during 2016- 17 at Department of Plant Pathology, S.K.N. College of Agriculture, Jobner, Jaipur (Rajasthan). Diseased samples were collected from agronomy farm, S.K.N. college of agriculture, Jobner. Isolation of the pathogen was made from roots of chickpea and purified by hypal tip method. The pathogenicity of the fungus was proved by seed and soil inoculation techniques where higher disease incidence was recorded with soil inoculation technique. The isolated fungus was identified on the basis of morphological 
characters. The culture was also sent to ITCC, division of plant pathology, iari, NEW DELHI for further confirmation or identification of fungus. The fungus was identified as Macrophomina phaseolina (tassi.) Goid with (id no. 6621).

\section{Integrated management against dry root rot of chickpea}

Prior to sowing, pots $(30 \mathrm{~cm}$ diameter) were sterilized with copper sulphate solution and filled with sterilized soil + FYM (Soil : FYM $=3: 1$; sterilized at $1.045 \mathrm{~kg} / \mathrm{cm} 2$ for one hour for three consecutive days). These pots were inoculated with inoculum, multiplied on sorghum grains @ 20 g/pot. 10 apparently healthy and surface sterilized chickpea seeds (L-550) were sown in each pot with four replications. Surface sterilized seeds sown in uninoculated sterilized soil, served as check. These pots were kept in cage house and watered regularly as and when required and maintained under identical conditions.

The most effective treatments viz., organic amendment through neem cake, seed treatment with fungicides (bavistin), plant extract (garlic) and bio agents (Trichoderma viride) in combination with each other were evaluated to see their combined effect on root rot incidence. Neem cake mixed with unsterilized soil contained in earthern pots were allowed to decompose for a week. The pots were then inoculated with $M$. phaseolina (a) $20 \mathrm{~g} /$ pot and under polythene cover for few days. After 7 day of inoculation seed of chickpea treated with requisite quantity of fungicide, bioagent and plant extract were sown in pots. Three replications for each treatment were maintained. A control treatment without any amendments and sown with untreated seeds was also kept for comparison. The pots were watered as when required. All the pots were maintained under identical condition. Observation on root rot incidence of chickpea seedling was recorded on 40 and 60 DAS was calculated by following formula.

Number of diseased plants

$\%$ root rot incidence $=$-------------- $\times 100$

Total number of plants

\section{Reaction of different cultivars/ germplasm against dry root rot chickpea}

Twenty nine cultivar/ germplasm of chickpea received from RARI, Durgapura (Raj.) were evaluated against dry root rot under pot condition during Rabi 2016-17. Inoculum multiplied on sorghum medium was applied in pot at $20 \mathrm{~g} /$ pot to increase the disease pressure. Inoculum was added before sowing. Seeds were washed thoroughly with sterilized water. 10 seeds of each chickpea cultivars/ germplasm were sown in each pot. Three replication were maintained under pot condition. Observations were recorded after 40 days of sowing and continued up to 60 days on the basis of disease incidence and varieties were categorized according to their reaction against the disease as per criterion.

Categorization of chickpea genotypes into different disease reactions used the ICRIP scale (Nagamma et al., 2015)

\begin{tabular}{|l|l|}
\hline Category & $\begin{array}{l}\text { Per cent disease } \\
\text { incidence }\end{array}$ \\
\hline Immune & $\mathbf{0}$ \\
Resistant & $\mathbf{1 - 1 0 \%}$ \\
Moderately resistant & $\mathbf{1 1 - 2 0 \%}$ \\
Moderately Susceptible & $\mathbf{2 1 - 3 0 \%}$ \\
Susceptible & $\mathbf{3 1 - 5 0 \%}$ \\
Highly susceptible & More than 50\% \\
\hline
\end{tabular}

The following varieties were used against dry root of chickpea phule $\mathrm{G}-408108$, H 12-62, GNG- 1958, IPC 2012-31, CSJ- 1001, CSJK96, GNG- 2299, IPC 10-134, Phule G 0719- 
10, GNG 2304, PG 0104, IPCK 2009 -165, GL 12003, JG 74315, BG 3069, H 12- 26, IPC 2007 -28, BG- 3068, CSJ 515, BG 3064, NDG 14- 24, CSJK 114, NBeG 807, DBGV 3205, BG 0109, BG 3054, NBeG 738, CSJK 46 and L-550. The disease incidence of root rot was recorded for each cultivar/ germplasm lines.

No. of infected Plants

Disease incidence $=$ X 100

Total plant

\section{Results and Discussion}

\section{Integrated management}

Root rot of chickpea caused by Macrophomina phaseolina is a soil borne disease. Currently the only approach to control the disease is the use of chemicals which in addition to being costly and disturbs the soil ecology. An experiment was conducted to determine the compatibility of biocontrol agent, organic amendments, plant extract with commercially effective fungicides which were found effective under in vivo condition were evaluated with different combinations. The experiment was conducted for management of the disease by combinations of soil treatment with Neem cake, seed treatment with fungicide, bio-agent and garlic clove extract. The results depicted in Table 2 revealed that all fungicides, plant extract, bio - agents and organic amendments were found significantly superior over control in reducing per cent disease control at 40 and 60 days after sowing. Among the treatments, treatment T6 is found most effective against dry root rot of chickpea and reducing the per cent disease incidence soil application with neem cake @ 25g/pot + seed treatment with carbendazim @ $2 \mathrm{~g} / \mathrm{kg}$ seed (16.66 and 20.00\%) followed by seed treatment with Trichoderma viride @ $4 \mathrm{~g} / \mathrm{kg}$ seed + carbendazim @ 2 g/kg seed (20.00 and $20.83 \%$ ). reducing root rot incidence over control at 40 and 60 days after sowing respectively.
Maximum disease control over check was recorded the treatments soil treatment with neem cake@25g/pot+ seed treatment with carbendazim@2g/kg seed (64.24 and 68.00 $\%)$ seed (46.35 and 67.52\%) over control at 40 and 60 days after sowing respectively. Sayyad et al., (2015) worked on chickpea Cv. JG-62 seeds treated with carbendazim was recorded highest seed germination (90.0\%) least disease incidence (14.0\%) and maximum disease control (86.0\%). Among bioagents, Trichoderma viride was recorded highest seed germination $(92.0 \%)$, least disease incidence $(31.1 \%)$, and maximum disease control $(68.8 \%)$ among organic amendments, by neem cake was found to be significantly higher germination and resulted next higher $85.3 \%$ disease control.

Dhingani and Solanky (2016) worked on the efficacy of various Bioagents viz. Tricoderma viride and T. harzianum, Oil cakes viz. neem cake and castor cake, FYM and Carbendanzim through seed treatment and soil application were evaluated against Macrophomina phaseolina (Tassi.) Goid causing root rot disease of Chickpea. Integrated management study of root rot disease of chickpea under field condition showed that soil application of T.harzianum @ $5 \mathrm{~kg}$ in $500 \mathrm{~kg}$ neem cake/ha in furrow 5 days prior to sowing resulted in higher seed germination $(74.90 \%)$ and lowest disease incidence $(11.81 \%)$ and gave highest yield $(1553 \mathrm{~kg} / \mathrm{ha})$.

Tetali et al., (2016) reported the use of Trichoderma viride along with neem cake produced the higher germination percentage and shoot length, respectively as compared to their separate use. Soil amendment with neem cake and seed treatment with TNAU isolate of $T$. viride significantly reduced the per cent disease incidence. Evaluation of cultivars/ germplasms of chickpea against dry root rot of chickpea. 
Evaluation of cultivars/ germplasms of chickpea against dry root rot of chickpea

Twenty nine cultivars were screened against Macrophomina phaseolina under artificial conditions. None of variety was found immune or resistant to dry root rot. Entries H12-62, GNG 1958, IPC 2002-31, GNG 2299, IPC 10- 134, PG 0104, IPCK 2009 -165, GL 2003, H 12-26, IPC 2007-28, CSJ 515 and BG 0109 were observed moderately resistance, Phule G 08108, CSJ 1001, CSJK 96, Phule G 0719-10, GNG 2304, JG 74315, BG 3069, BG 3054, NbeG 738 and CSJK 46 were found moderately susceptible, BG 3068, BG 3064, NDG 14-24,CSJK 114, NBeG 807 and DBGV 3205 were observed susceptible and L- 550 (Check) were found highly susceptible (Table: 3). Jayalakshmi et al., (2009) were conducted a pot culture experiment for screening of chickpea breeder promising entries(12\%) susceptible check JG- 62 during rabi season of 2004- 2005 and 2005- 2006. Out of 12 genotypes tested against root rot disease 4 were found resistant, 2 were moderately susceptible, 3 were susceptible and 3 were highly susceptible to dry root rot disease. Khan et al., (2013) reported management of chickpea dry root rot through resistance germplasm lines in Jammu \& Kashmir. Sixty germplasm lines of chickpea were screened for their resistance against dry root rot disease in pot. Only nine lines namely KGD-1189, KGD-1201, KGD-1209, KGD-1215, KGD1217, KGD-1220, KGD-1221, KGD-1248 and KGD-1289 were found resistance. Nagamma et al., (2015) were screened chickpea entries against dry root rot disease in sick plot. They observed that only thirteen entries viz. GNG1958 (AVT-2), GNG-1999, CSJ-303, NG3004, CSJ-753, RSG-888, PhuleG-04305, IPCK-07-62, RVSSG-12, HK-08-212, Phule G-09305, AKG-2002-1K and ICCV-08317 showed resistant reaction under field condition.

Table.1 Combination of bio-agent, fungicide, plant extract and organic amendment tested against dry root rot of chickpea (in vivo)

\begin{tabular}{|l|l|}
\hline TREATMENTS & \multicolumn{1}{|c|}{ TREATMENTS } \\
\hline $\mathrm{T}_{1}$ & $\begin{array}{l}\text { SEED TREATMENT WITH TRICHODERMA VIRIDE @ 4G/KG SEED+ } \\
\text { GARLIC EXTRACT @ 10\% }\end{array}$ \\
\hline $\mathrm{T}_{2}$ & $\begin{array}{l}\text { SEED TREATMENT WITH TRICHODERMA VIRIDE @ 4G/KG SEED } \\
\text { +SOIL APPLICATION WITH NEEM CAKE@ 25G/POT. }\end{array}$ \\
\hline $\mathrm{T}_{3}$ & $\begin{array}{l}\text { SEED TREATMENT WITH TRICHODERMA VIRIDE @ 4G/KG SEED + } \\
\text { CARBENDAZIM @ 2G/KG SEED. }\end{array}$ \\
\hline $\mathrm{T}_{4}$ & $\begin{array}{l}\text { SEED TREATMENT WITH GARLIC EXTRACT@ 10\%+SOIL } \\
\text { APPLICATION WITH NEEM CAKE @ 25G/POT. }\end{array}$ \\
\hline $\mathrm{T}_{5}$ & $\begin{array}{l}\text { SEED TREATMENT WITH GARLIC EXTRACT@ 10\%+ CABENDAZIM } \\
\text { @2 G/KG SEED. }\end{array}$ \\
\hline $\mathrm{T}_{6}$ & $\begin{array}{l}\text { SOIL APPLICATION WITH NEEM CAKE@ 8T/HA + SEED } \\
\text { TREATMENT WITH CARBENDAZIM @ 2G/KG SEED. }\end{array}$ \\
\hline 7. & CONTROL (UNTREATED) \\
\hline
\end{tabular}


Table.2 Integrated management of dry root rot of chickpea (in pots)

\begin{tabular}{|c|c|c|c|c|}
\hline \multirow[t]{2}{*}{ Treatments } & \multirow{2}{*}{$\begin{array}{l}\text { Per cent disease } \\
\text { incidence } \\
\text { 40 DAS }\end{array}$} & \multirow{2}{*}{$\begin{array}{c}\text { Per cent disease } \\
\text { control } \\
\text { 60 DAS }\end{array}$} & & \\
\hline & & & $\begin{array}{c}40 \\
\text { DAS }\end{array}$ & $\begin{array}{c}60 \\
\text { DAS }\end{array}$ \\
\hline \multirow{2}{*}{$\begin{array}{l}\mathrm{T}_{1} \text { Seed treatment with } \\
\text { Trichoderma viride @ } 4 \mathrm{~g} / \mathrm{kg} \\
\text { seed + garlic extract @ } 10 \%\end{array}$} & 40.00 & 44.44 & 14.16 & 28.89 \\
\hline & (39.23) & (41.81) & & \\
\hline \multirow{2}{*}{$\begin{array}{l}\mathrm{T}_{2} \text { Seed treatment with } \\
\text { Trichoderma viride @ } 4 \mathrm{~g} / \mathrm{kg} \\
\text { seed + soil application with } \\
\text { neem cake @ } 25 \mathrm{~g} / \text { pot }\end{array}$} & 26.60 & 27.27 & 42.91 & 56.36 \\
\hline & (31.05) & (31.48) & & \\
\hline \multirow{2}{*}{$\begin{array}{l}\mathrm{T}_{3} \text { Seed treatment with } \\
\text { Trichoderma viride@ } 4 \mathrm{~g} / \mathrm{kg} \\
\text { seed + carbendazim @ } 2 \mathrm{~g} / \mathrm{kg} \\
\text { seed. }\end{array}$} & 20.00 & 20.83 & 46.35 & 67.52 \\
\hline & (26.57) & $(27.15)$ & & \\
\hline \multirow{2}{*}{$\begin{array}{l}\mathrm{T}_{4} \text {. Seed treatment with } \\
\text { garlic extract @ } 10 \%+\text { soil } \\
\text { application with neem cake } \\
\text { @ 25g/pot }\end{array}$} & 30.00 & 33.33 & 35.62 & 46.67 \\
\hline & $(33.21)$ & $(35.26)$ & & \\
\hline \multirow{2}{*}{$\begin{array}{l}\mathrm{T}_{5} \text { Seed treatment with } \\
\text { garlic extract @ } 10 \%+ \\
\text { carbendazim @ } 2 \mathrm{~g} / \mathrm{kg} \text { seed }\end{array}$} & 23.33 & 30.43 & 50.00 & 51.31 \\
\hline & (28.88) & (33.48) & & \\
\hline \multirow{2}{*}{$\begin{array}{l}\mathrm{T}_{6} . \text { Soil application with } \\
\text { neem cake @ } 25 \mathrm{~g} / \mathrm{pot}+\text { seed } \\
\text { treatment with carbendazim } \\
\text { @ } 2 \mathrm{~g} / \mathrm{kg} \text { seed }\end{array}$} & 16.66 & 20.00 & 64.24 & 68.00 \\
\hline & (24.09) & $(26.57)$ & & \\
\hline \multirow[t]{2}{*}{ Control } & 46.60 & 62.50 & - & - \\
\hline & (43.05) & (52.24) & & \\
\hline $\mathrm{SEm} \pm$ & 1.50 & 1.54 & & \\
\hline $\mathrm{CD}(\mathrm{p}=0.05)$ & 4.62 & 4.74 & & \\
\hline
\end{tabular}

* Average of three replications

Figures given in parentheses are angular transformed values 
Table.3 Evaluation of cultivars/ germplasms of chickpea against dry root rot of chickpea

\begin{tabular}{|c|c|c|c|}
\hline S.No. & $\begin{array}{l}\text { Name of cultivar } \\
\text { /germplasms }\end{array}$ & $\begin{array}{c}\text { Disease incidence } \\
(\%)\end{array}$ & $\begin{array}{l}\text { Reaction of } \\
\text { cultivars/ } \\
\text { germplasms }\end{array}$ \\
\hline 1 & Phule G 08108 & $23.80(29.20)$ & MS \\
\hline 2 & H $12-62$ & $19.00(25.84)$ & MR \\
\hline 3 & GNG- 1958 & $15.62(23.28)$ & MR \\
\hline 4 & IPC 2002-31 & $13.80(21.81)$ & MR \\
\hline 5 & CSJ 1001 & $28.60(32.33)$ & MS \\
\hline 6 & CSJK 96 & $26.70(31.11)$ & MS \\
\hline 7 & GNG 2299 & $17.65(24.84)$ & MR \\
\hline 8 & IPC 10-134 & $15.50(23.18)$ & MR \\
\hline 9 & PhuleG0719-10 & $23.00(28.66)$ & MS \\
\hline 10 & GNG 2304 & $28.75(32.42)$ & MS \\
\hline 11 & PG 0104 & $12.72(20.89)$ & MR \\
\hline 12 & IPCK 2009-165 & $19.00(25.84)$ & MR \\
\hline 13 & GL 12003 & $17.60(24.80)$ & MR \\
\hline 14 & JG 74315 & $22.40(28.25)$ & MS \\
\hline 15 & BG 3068 & $29.70(33.02)$ & MS \\
\hline 16 & H $12-26$ & $14.66(22.51)$ & MR \\
\hline 17 & IPC 2007-28 & $18.00(25.10)$ & MR \\
\hline 18 & BG 3068 & $31.20(33.96)$ & S \\
\hline 19 & CSJ 515 & $16.21(23.74)$ & MR \\
\hline 20 & BG 3064 & $34.50(35.97)$ & $\mathrm{S}$ \\
\hline 21 & NDG 14-24 & $38.30(38.23)$ & $\mathrm{S}$ \\
\hline 22 & CSJK 114 & $37.25(37.61)$ & $\mathrm{S}$ \\
\hline 23 & NBeG 807 & $32.30(34.63)$ & $\mathrm{S}$ \\
\hline 24 & DBGV 3205 & $42.40(40.63)$ & $\mathrm{S}$ \\
\hline 25 & BG 0109 & $17.62(24.82)$ & MR \\
\hline 26 & BG 3054 & 26.66(31.09) & MS \\
\hline 27 & NBeG 738 & $24.44(29.63)$ & MS \\
\hline 28 & CSJK 46 & $27.72(31.77)$ & MS \\
\hline 29 & Check (L-550) & $60.00(50.77)$ & HS \\
\hline \multicolumn{2}{|c|}{$\mathrm{SEm} \pm$} & 0.81 & \\
\hline \multicolumn{2}{|c|}{$\mathrm{CD}(\mathrm{p}=0.05)$} & 2.50 & \\
\hline
\end{tabular}

Figure in parentheses are angular transformed values

Where, R- resistant, MR- Moderately resistant, MS- Moderately susceptible, S- Susceptible, HS- highly susceptible

In conclusion, management of dry root rot disease in chickpea there are no resistance varieties are available so applied integrated approaches for manage and reduce incidence of root rot disease. 


\section{References}

Bagri, R. K., Jain, S. C., Jain, K. L. and Sharma, P. (2004). Detection and control of seed borne fungi causing root rot diseases in chickpea. Journal of Mycology and Plant Pathology 34(2): 658-660

Dhingani, J. C. and Solanky, K. U. (2016). Integrated management of root rot disease [Macrophomina phaseolina (Tassi.) Goid] of chickpea through bioagents. Oil cakes, and chemicals under field condition in south Gujrat conditions. Plant Archives. 16(10): 183-186.

El-Araby, M.E, Kurle, J. E. and Stetina, S. R. (2009). First report of charcoal rot (Macrophomina phaseolina) on Soyabean in Minnesata. Plant Diseases. 87(2): 202.

Ferguson, BJ., Indrasumunar, A., Hayashi, S., Lin, MH., Lin, YH., Reid, DE. Gresshoff, PM. (2010). Molecular analysis of legumes nodules development and autoregulation. Journal of Integrated. Plant Biology. 52: 6176.

Ghosh, R., Sharma, M., Telangre, R., and Pande, S. (2013). Occurrence and distribution of Chickpea disease in central and southern part of India. American Journal of Plant Science 4: 940-944.

Jayalakshmi, S. K., Usharani, S., Benagi, V. L. and Mannur, D. M. (2009). Sources of resistance to dry root rot of chickpea caused by Rhizoctonia bataticola. Agril. Sci. Digest. 28(2) 147-148.

Khan, R.A., Towseef, A.B. and K. Krishna (2013). Screening of chickpea (Cicer arietinum L.) germplasm lines against dry root rot caused by Rhizoctonia bataticola (Taub.) Butler. Asian Pharm.Clin. Res. 6: 211-212

Khan, S. N. (2007). Macrophomina phaseolina as causal agent forcharcoal rot of sunflower. Mycopathology 5(2): 111-118

Mitra, M. (1931). Report of the imperial mycologist Sci. Rep. of the Agric. Res. Inst. 1929- 1930: 58-71.

Nagamma, G., Saifulla, M., Jabbar, S. and Pavitra, S. (2015).Screening of chickpea genotypes against dry root rot caused by Macrophomina phasealina. The Bioscan, 10 (4): 1795-1800.

Nagamma, G., Saifulla, M., Jabbar, S. and Pavitra, S. (2015). Screening of chickpea genotypes against dry root rot caused by Macrophomina phasealina. The Bioscan, 10 (4): 1795-1800.

Pal, M. (1998). Disease of pulse crops, their relative importance and management. Journal of Mycology and Plant Pathology. 28(2): 114122.

Pande S, Rao J N and Kishore GK. (2004). Evaluation of chickpea lines for resistance to dry root rot caused by Rhizoctonia bataticola. International Chickpea and Pigeonpea Newsletter 11: 37-38.

Pande, S. and Sharma, M. (2010). Impact of climate change on rain fed crop disease, seminar: Central Research Institute for Dryland Agriculture, Hyderabad, India. pp. 55-59.

Rangaswami, G. and Mahadevan, A. (2008). Diseases of crop plants in India (4th ed). New Delhi, PHI Learning Private Limited, page no. $275-278$.

Sayyad, S. I. Mogle, T. R., and Sonkamble, M. M. (2015). Effect of fungicides, bio - agents and organic amendments against Macrophomina phaseolina in chickpea. Annals of Plant Protection Science 23 (2): 355 -357.

Singh, S.K. and Srivastava, H.P. (1988). Symptoms of $M$. phaseolina infection on mothbean seedlings. Annals of Arid Zone, 27: 151-152.

Tetali, S.,Lakshman, P. and Bharat Chandra, P. (2016). Efficacy of biocontrol agents and organic amendments against root rot disease in black gram. International Journal of Plant Protection 9 (1): 279-282.

\section{How to cite this article:}

Lalita Lakhran and Ahir, R.R. 2018. Integrated Management and Host Plant Resistance Against Dry Root Rot [Macrophomina phaseolina (Tassi.) Goid] of Chickpea. Int.J.Curr.Microbiol.App.Sci. 7(07): 1266-1273. doi: https://doi.org/10.20546/ijcmas.2018.707.151 